\title{
MENTAL HEALTH OF HEALTH SCIENCE STUDENTS DURING COVID-19 PANDEMIC: A CROSS-SECTIONAL STUDY IN A MEDICAL COLLEGE OF NEPAL
}

Narayan Bahadur Mahotra, ${ }_{1}^{1}$ Sabita Kandel, ${ }^{1}$ Sanyukta Gurung, ${ }^{1}$ Bishal Joshi, ${ }^{2}$ Sagun Ballav Pant, ${ }^{3}$ Sait Pradhan,

\section{ABSTRACT}

\section{INTRODUCTION}

Mental health impact of COVID-19 is a well-known entity. Health science students are among the high risk groups for developing mental health issues due to lengthy and rigorous studies they undertake. This study aims to explore the mental health of health science undergraduate students of Maharajgunj Medical Campus, and Maharajgunj Nursing Campus during the COVID-19 pandemic in Nepal.

\section{MATERIAL AND METHODS}

A descriptive cross-sectional study was conducted from February 2021 to July 2021 using convenience sampling technique using Nepali version of DASS-21 to undergraduate health science students of Maharajgunj Medical Campus and Maharajgunj Nursing campus.

\section{RESULTS}

Out of 164 participants, depression, anxiety and stress was seen in 43\%, 33\% and 29\% respectively. Females showed more depression (47.6\%) and anxiety (38.8\%) and stress (32\%) as compared to males

\section{CONCLUSION}

Mental health of health science students is adversely affected during the COVID-19 pandemic.

\section{KEYWORDS}

COVID-19, DASS-21, Health Science Students, Mental Health

1. Department of Clinical Physiology, Maharajgunj Medical Campus, IOM, Kathmandu, Nepal.

2. Department of Clinical Physiology, Universal College of Medical Sciences, Bhairahawa, Nepal.

3. Department of Psychiatry, Institute of Medicine, Tribhuvan University, Kathmandu, Nepal

DOI: https://doi.org/10.3126/jucms.v9i02.42014

\author{
For Correspondence \\ Dr. Sabita Kandel \\ Department of Clinical Physiology \\ Maharajgunj Medical Campus \\ Kathmandu \\ Email:sabitakandel@gmail.com
}




\section{INTRODUCTION}

Medical education is known to require enormous time, unsocial hours and hard-work by the students. Stress, anxiety and depressive illness is found to be more common in health science students than others. ${ }^{1-4}$ In the present context, where around two billion people across 220 countries and territories have experienced the adverse impact of COVID-19, effect of this unprecedented situation on the overall health of these high risk group should not be overlooked. ${ }^{5.8}$ Limitations imposed during lockdown and the panic situation during COVID era have been known to affect overall health of every individual, more so for the high risk groups such as health science students. ${ }^{2,3,9,10}$

Many institutes across the world are closed due to COVID-19 due to which students had to solely rely on virtual learning for academic activities. ${ }^{1}$ The absence of classes, lack of direct supervision by the teachers, transition to online teaching and requirement of technical expertise for effective virtual learning has created a completely different environment for students to adjust and cope. Also, health science students are likely to have minimal practical and clinical exposure during the pandemic which may affect their skill domain. ${ }^{1.8}$ In such context, health science students are likely to experience apprehension, inability to cope and other mental health issues in the presence of preexisting academic burden as well as the extra burden to cope to a new way of learning. ${ }^{2,3,6,9}$

Many studies have shown the notable effect of COVID-19 on the mental health of students and other professionals. ${ }^{9 \cdot 11}$ In a prospective longitudinal study conducted in India before and during the COVID outbreak, it was shown that there was significant increase in the level of anxiety and stress on medical students during the outbreak in comparison to before the outbreak. ${ }^{12}$ Similarly, cross-sectional study and online survey conducted in United States on medical student reported that medical students experience significant level of depression, anxiety and stress. ${ }^{13,14}$ In context of Nepal, very few published studies could be traced regarding the mental health impact of COVID, particularly in health science students. ${ }^{2.4}$ Hence this study aims to explore the mental health of health science students during the COVID pandemic in Nepal.

\section{MATERIAL AND METHODS}

A descriptive cross-sectional study was conducted from February 2021 to July 2021 with the approval from Ethical Review Committee (Ref: 336(6-11) ${ }^{\mathrm{E} 2}$ 077-078) of Institute of Medicine, Maharajgunj, Kathmandu. Convenience sampling was adopted for this study. A self-administered questionnaire based on depression anxiety and stress scale-21 items (DASS-
21) was used. A google form that included inclusion and exclusion criteria of the study, information regarding the study and a validated Nepali version of DASS-21 and demographics, was prepared and distributed online among the undergraduate health science students. All students enrolled in the undergraduate health science programme of Maharajgunj Medical Campus and Maharajgunj Nursing Campus, who were in their preclinical years (first two years of medical education) at the time of data collection, who did not have known mental health disease and who were not on medication for any psychiatric illness, were eligible to participate in the study.

DASS-21 was used as a screening tool which is a well validated for screening of anxiety and depression with a very high sensitivity and specificity. ${ }^{15-18}$ Nepali version of DASS21 translated and validated elsewhere was used in this study. ${ }^{15}$ This tool contained 21 items with seven items in each of the three sub-scales: depression, anxiety and stress. Response in each items ranged from 0 (did not apply to me at all) to 3 (applied to me very much) in a 4 point likert scale. Item $3,5,10,13,16,17,21$ belonged to depression subscale, item $2,4,7,9,15,19,20$ belonged to anxiety subscale and item $1,6,8,11,12,14,18$ belonged to stress subscale in Nepali version of DASS21.

Scores for each subscale in DASS 21 was calculated as per the DASS manual. Total score for depression subscale was considered as 0-4 normal, 5-6 mild, 7-10 moderate, 11-13 severe, 14 or more extremely severe. Total score for anxiety subscale was considered as 0-3 normal, 4-5 mild, 6-7 moderate, $8-9$ severe, 10 or more, extremely severe. Total stress score was considered as 0-7 normal, 8-9 mild, 10-12 moderate, $13-16$ severe and 17 and more extremely severe. ${ }^{17,18}$

A pilot study with the sample of 30 students was conducted to examine the validity and reliability of the tool. Reliability of the tool was assessed with cronbach's alpha with the value of 0.82 for depression sub-scale, 0.79 for anxiety sub-scale and 0.84 for stress sub-scale. Convergent validity of DASS-21 showed the significant correlation $(\mathrm{p}<0.05)$ of more than 0.36 for depression, anxiety and stress construct.

SPSS software version 16 was used for statistical analysis. Descriptive statistics such as mean and standard deviations was calculated for the continuous variables and absolute numbers and percentages for the categorical variables. Chi square tests was used for categorical variables. Level of significance was set at 0.05

\section{RESULTS}

The DASS-21 questionnaire was sent to 335 students among which $164(49 \%)$ responded. The majority of the participants 
were females 103 (62.8\%) and 61 (37.2\%) were males. Most of the participants were form the Nursing discipline 65 (39.6\%). The mean age of the students was $21.39 \pm 2.45$ years as illustrated in table 1.

Table 1. General characteristics or the participants in accordance to course of study

\begin{tabular}{lll|l}
\hline Course & N (\%) & Gender & \multicolumn{2}{l}{} \\
\cline { 3 - 4 } & & $\begin{array}{l}\text { Male } \\
\text { N }(\%)\end{array}$ & $\begin{array}{l}\text { Female } \\
\text { N }(\%)\end{array}$ \\
\hline Allied health & $27(16.5 \%)$ & $13(21.3 \%)$ & $14(13.6 \%)$ \\
Dental & $18(11 \%)$ & $9(14.8 \%)$ & $9(8.7 \%)$ \\
MBBS & $54(32.9 \%)$ & $36(59 \%)$ & $18(17.5 \%)$ \\
Nursing & $65(39.6 \%)$ & $3(4.9 \%)$ & $62(60.2 \%)$ \\
Total & $164(100 \%)$ & $61(37.2 \%)$ & $103(62.8 \%)$ \\
\hline
\end{tabular}

Majority of the students had normal depression score (56.7\%), anxiety score $(62.8 \%)$ and stress score $(71.3 \%)$. The female participants $(47.6 \%)$ had a more altered depression scale according to DASS2 1 in comparison to their male counterparts $(36.1 \%)$. The anxiety scale was also deranged more among the female participants $(38.8 \%)$ in comparison to the male participants $(34.4 \%)$. The stress scale depicted similar results where $32 \%$ female participants had more abnormal stress scores whereas, only $23 \%$ male participants had abnormal scores. No significant association was seen in normal and altered categories in depression, anxiety and stress among the male and female participants as illustrated in table 2.

Table 2. Mental health among the participants in accordance to gender

\begin{tabular}{|c|c|c|c|c|}
\hline \multirow{2}{*}{$\begin{array}{l}\text { Mental } \\
\text { Status }\end{array}$} & \multirow{2}{*}{$\begin{array}{l}\text { Total } \\
\mathrm{N}(\%, 95 \mathrm{CI})\end{array}$} & \multicolumn{2}{|l|}{ Gender } & \multirow[b]{2}{*}{$\begin{array}{l}\text { Chi- } \\
\text { square } \\
\text { test; } \\
\text { P- } \\
\text { value }\end{array}$} \\
\hline & & $\begin{array}{l}\text { Males } \\
\mathrm{N}(\%, 95 \mathrm{CI})\end{array}$ & $\begin{array}{l}\text { Females } \\
\mathrm{N}(\%, 95 \mathrm{CI})\end{array}$ & \\
\hline \multicolumn{5}{|l|}{ Depression } \\
\hline Normal & $93(56.7 \%, 49.1-64.3)$ & $39(63.9 \%, 51.8-76)$ & $54(52.4 \%, 42.8-62)$ & \multirow{6}{*}{$\begin{array}{l}2.1 \\
0.15\end{array}$} \\
\hline Mild & $26(15.9 \%, 9.5-20.5)$ & $7(11.5 \%, 3.5-19.5)$ & $19(18 \%, 10.9-25.9)$ & \\
\hline Moderate & $32(19.5 \%, 13.4-25.6)$ & $11(18 \%, 8.3-27.6)$ & $21(20 \%, 12.6-28.2)$ & \\
\hline Severe & $6(3.7 \%, 0.8-6.6)$ & $1(1.6 \%, 0-4.7)$ & $5(4.9 \%, 0.7-9.1)$ & \\
\hline Extremely & $7(4.3 \%, 1.2-7.4)$ & $3(4.9 \%, 0-10.3)$ & $4(3.9 \%, 0.2-7.6)$ & \\
\hline Severe & - & - & - & \\
\hline \multicolumn{5}{|l|}{ Anxiety } \\
\hline Normal & $103(62.8 \%, 55.4-70.2)$ & $40(66 \%, 53.7-77.5)$ & $63(61 \%, 51.8-70.6)$ & \multirow{5}{*}{$\begin{array}{l}0.32 \\
0.57\end{array}$} \\
\hline Mild & $24(14.6 \%, 9.2-20)$ & $6(9.8 \%, 2.3-17.3)$ & $18(18 \%, 10.2-25.8)$ & \\
\hline Moderate & $18(11 \%, 6.2-15.8)$ & $9(14.8 \%, 5.9-23.7)$ & $9(8.7 \%, 3.3-14)$ & \\
\hline Severe & $12(7.3 \%, 3.3-11.3)$ & $3(4.9 \%, 0-10.3)$ & $9(8.7 \%, 3.3-14)$ & \\
\hline $\begin{array}{l}\text { Extremely } \\
\text { Severe }\end{array}$ & $7(4.3 \%, 1.2-7.4)$ & $3(4.9 \% 0-10.3)$ & $4(3.9 \%, 0.2-7.6)$ & \\
\hline \multicolumn{5}{|l|}{ Stress } \\
\hline Normal & $117(71.3 \%, 64.4-78.2)$ & $47(77 \%, 66.487 .6)$ & $70(68 \%, 59-77)$ & \multirow{6}{*}{$\begin{array}{l}1.5 \\
0.21\end{array}$} \\
\hline Mild & $28(17.1 \%, 11.3-22.9)$ & $8(13.1 \%, 4.6-21.6)$ & $20(19.4 \%, 11.8-27)$ & \\
\hline Moderate & $9(5.5 \%, 2-9)$ & $3(4.9 \%, 0-10.3)$ & $6(5.8 \%, 1.3-10.3)$ & \\
\hline Severe & $7(4.3 \%, 1.2-7.4)$ & $2(3.3 \%, 0-7.8)$ & $5(4.9 \%, 0.7-9.1)$ & \\
\hline $\begin{array}{l}\text { Extremely } \\
\text { Severe }\end{array}$ & $3(1.8 \%, 0-3.8)$ & $1(1.6 \%, 0-4.7)$ & $2(1.9 \%, 0-4.5)$ & \\
\hline Total $(\mathrm{n} \%)$ & $164(100 \%)$ & $61(37.2 \%)$ & $103(62.8 \%)$ & \\
\hline
\end{tabular}

The students from the Dental stream had the most altered depression scale scores $(50 \%)$ followed by Allied health sciences (48.1\%), MBBS (46.3\%) and Nursing (36.9\%) respectively. The anxiety scale was most deranged among the Allied health science students (48.1\%), followed by Dental (44.4\%), Nursing (33.8\%) and MBBS (33.3\%) students. The stress scale was most altered among Dental students (38.9\%) followed by Allied health science (37\%), MBBS (27.8\%) and Nursing (23.4\%) students respectively. No significant association was seen in normal and altered categories in depression, anxiety and stress among para medical and medical students as illustrated in table 3 .

Table 3. Mental Health among the participants in accor dance to course of study

\begin{tabular}{|c|c|c|c|c|c|}
\hline \multirow{3}{*}{$\begin{array}{l}\text { Mental } \\
\text { Status }\end{array}$} & \multicolumn{4}{|l|}{ Course of study } & \multirow{3}{*}{$\begin{array}{l}\text { Chi- } \\
\text { square } \\
\text { test; P- } \\
\text { value }\end{array}$} \\
\hline & \multicolumn{2}{|l|}{ Para medical } & \multicolumn{2}{|l|}{ Medical } & \\
\hline & $\begin{array}{l}\text { Allied } \\
\mathrm{N}(\%, 95 \mathrm{CI})\end{array}$ & $\begin{array}{l}\text { Nursing } \\
\mathrm{N}(\%, 95 \mathrm{CI})\end{array}$ & $\begin{array}{l}\text { Dental } \\
\mathrm{N}(\%, 95 \mathrm{CI})\end{array}$ & $\begin{array}{l}\text { MBBS } \\
\text { N(\%,95 } \\
\text { CI })\end{array}$ & \\
\hline $\begin{array}{l}\text { Depressio } \\
\mathbf{n} \\
\text { Normal }\end{array}$ & $14(52 \%, 33-71)$ & $41(63 \%, 51-75)$ & $9(50 \%, 27-73)$ & $\begin{array}{l}29(54 \%, 40 \\
67)\end{array}$ & $\begin{array}{l}0.81 \\
0.37\end{array}$ \\
\hline Mild & $3(11 \%, 0-22.9)$ & $13(20 \%, 10-30)$ & $\begin{array}{l}2(11 \%, 0- \\
25.6)\end{array}$ & $\begin{array}{l}8(15 \%, 5- \\
24)\end{array}$ & \\
\hline Moderate & $8(30 \%, 12-47)$ & $8(12.3 \%, 4-20)$ & $\begin{array}{l}4(22 \%, 3- \\
41.4)\end{array}$ & $\begin{array}{l}12(22 \%, 11 \\
33)\end{array}$ & \\
\hline Severe & - & $1(1.5 \%, 0-4.5)$ & $\begin{array}{l}2(11.1 \%, 0- \\
26)\end{array}$ & $\begin{array}{l}3(5.6 \%, 0- \\
11.7)\end{array}$ & \\
\hline $\begin{array}{l}\text { Extremely } \\
\text { Severe }\end{array}$ & $2(7 \%, 0-17.3)$ & $2(3.1 \%, 0-7.3)$ & $1(6 \%, 0-16.2)$ & $\begin{array}{l}2(3.7 \%, 0- \\
8.7)\end{array}$ & \\
\hline Anxiety & & & & & \\
\hline Normal & $14(51.9 \%, 33-71)$ & $43(66 \%, 55-78)$ & $\begin{array}{l}10(56 \%, 33- \\
79)\end{array}$ & $\begin{array}{l}36(67 \%, 54 \\
79)\end{array}$ & $\begin{array}{l}0.65 \\
0.80\end{array}$ \\
\hline Mild & $6(22 \%, 6.5-37.9)$ & $12(19 \%, 9-27.9)$ & $\begin{array}{l}2(11 \%, 0 \\
25.6)\end{array}$ & $\begin{array}{l}4(7.4 \%, 0.4 \\
14)\end{array}$ & \\
\hline Moderate & $2(7.4 \%, 0-17.3)$ & $5(7.7 \%, 1.2-14)$ & $\begin{array}{l}2(11 \%, 0 \\
25.6)\end{array}$ & $\begin{array}{l}9(17 \%, 7- \\
27)\end{array}$ & \\
\hline Severe & $2(7.4 \%, 0-17.3)$ & $5(7.7 \%, 1.2-14)$ & $\begin{array}{l}3(17 \%, 0 \\
33.9)\end{array}$ & $\begin{array}{l}2(3.7 \%, 0- \\
8.7)\end{array}$ & \\
\hline $\begin{array}{l}\text { Extremely } \\
\text { Severe }\end{array}$ & $3(11.1 \%, 0-22.9)$ & - & $\begin{array}{l}1(5.6 \%, 0- \\
16.2)\end{array}$ & $\begin{array}{l}3(5.6 \%, 0- \\
11.7)\end{array}$ & \\
\hline \multicolumn{6}{|l|}{ Stress } \\
\hline Normal & $17(63 \%, 45-81)$ & $50(77 \%, 67-87)$ & $\begin{array}{l}11(61 \%, 39- \\
84)\end{array}$ & $\begin{array}{l}39(72 \%, 60 \\
84)\end{array}$ & $\begin{array}{r}0.23 \\
0.64\end{array}$ \\
\hline Mild & $5(18.5 \%, 4-33)$ & $10(15 \%, 7-24)$ & $\begin{array}{l}4(22 \%, \\
41.4)\end{array}$ & $\begin{array}{l}9(16.7 \%, 7- \\
27)\end{array}$ & \\
\hline Moderate & $1(3.7 \%, 0-10.8)$ & $3(4.6 \%, 0-9.7)$ & $\begin{array}{l}1(5.6 \%, 0- \\
16.2)\end{array}$ & $\begin{array}{l}4(7 \%, 0.4- \\
14.4)\end{array}$ & \\
\hline Severe & $4(15 \%, 1.4-28.2)$ & $1(1.5 \%, 0-4.5)$ & $\begin{array}{l}2(11.1 \%, 0- \\
26)\end{array}$ & & \\
\hline $\begin{array}{l}\text { Extremely } \\
\text { Severe }\end{array}$ & - & $1(1.5 \%, 0-4.5)$ & - & $\begin{array}{l}2(3.7 \%, 0- \\
8.7)\end{array}$ & \\
\hline
\end{tabular}

The majority of the students were above the age of 20 years. The majority of the students reported normal status in depression, anxiety and stress. No significant association was seen in normal and altered categories among the age group less than 20 years and more than 20 years as illustrated in table 4. 
Table 4. Mental health according to age group

\begin{tabular}{|c|c|c|c|}
\hline \multirow[t]{2}{*}{ Mental Status } & \multicolumn{2}{|l|}{ Age groups in years } & \multirow{2}{*}{$\begin{array}{l}\text { Chi-square test; } \mathrm{P} \text { - } \\
\text { value }\end{array}$} \\
\hline & $<20$ & $>20$ & \\
\hline \multicolumn{4}{|l|}{ Depression } \\
\hline Normal & $37(56.1 \%, 44.1-68.1)$ & $56(57.1 \%, 47.3-66.9)$ & $0.19 ; 0.89$ \\
\hline Mild & $10(15.2 \%, 6.5-23.9)$ & $16(16.3 \%, 9-23.6)$ & \\
\hline Moderate & $13(19.7 \%, 10.1-29.3)$ & $19(19.4 \%, 11.6-27.2)$ & \\
\hline Severe & $4(6.1 \%, 0.3-11.9)$ & $2(2 \%, 0-4.8)$ & \\
\hline Extremely Severe & $2(3 \%, 0-7.1)$ & $5(5.1 \%, 0.7-4.80$ & \\
\hline \multicolumn{4}{|l|}{ Anxiety } \\
\hline Normal & $44(66.7 \%, 55.3-78.1)$ & $59(60.2 \%, 50.5-69.9)$ & $0.71 ; 0.40$ \\
\hline Mild & $8(12.1 \%, 4.2-20)$ & $26(16.3 \%, 9.0-23.6)$ & \\
\hline Moderate & $8(12.1 \%, 4.2-20)$ & $10(10.2 \%, 4.2-16.2)$ & \\
\hline Severe & $3(4.5 \%, 0-9.5)$ & $9(9.2 \%, 3.5-14.9)$ & \\
\hline Extremely Severe & $3(4.5 \%, 0-9.5)$ & $4(4.1 \%, 0.2-8)$ & \\
\hline \multicolumn{4}{|l|}{ Stress } \\
\hline Normal & $47(71.2 \%, 60.3-82.1)$ & $70(71.4 \%, 62.5-80.3)$ & $0.01 ; 0.98$ \\
\hline Mild & $11(16.7 \%, 7.7-25.7)$ & $17(17.3 \%, 9.8-24.8)$ & \\
\hline Moderate & $4(6.1 \%, 0.3-11.9)$ & $5(0.05 \%, 0.7-9.5)$ & \\
\hline Severe & $3(4.5 \%, 0-9.5)$ & $4(0.04 \%, 0.17-8)$ & \\
\hline Extremely Severe & $1(1.5 \%, 0-4.4)$ & $2(0.02 \%, 0-0.05)$ & \\
\hline Total N (\%) & $66(40.2 \%)$ & $98(59.8 \%)$ & \\
\hline
\end{tabular}

\section{DISCUSSION}

In the present study, we assessed mental health of health science students of a medical college during COVID pandemic. It was demonstrated that $43 \%$ of the participants were depressed, $33 \%$ of the participants were anxious and $29 \%$ of the participants had different degrees of stress. The prevalence of depression in the present study is slightly higher than the prevalence of depression in medical students during non COVID situation worldwide and in Nepal as quoted by other studies. ${ }^{19,20,22,23}$ This could probably be explained by presence of extra stressors and unfamiliar situation during COVID pandemic. ${ }^{20}$ This study also showed higher prevalence of depression in female participants $(48 \%)$ than male participants $(36 \%)$. This finding supports the already known fact that females tend to have higher prevalence of depression than male. However, no significant association was seen statistically between females and depression. ${ }^{21}$ Similarly, prevalence of anxiety and stress among the health science students was 33\% and 29\% respectively. This finding from the study is similar to other study by Basheti et al done in Jordan. ${ }^{24}$ On stream wise analysis, most of the dental students had altered depression scale (50\%) as well as stress (48\%) and most of allied health sciences students had altered anxiety scale (39\%). This finding will be less reliable considering the small number of participants in dental (11\%) and allied health sciences $(16.5 \%)$ stream. Similarly, on age wise analysis, students less than 20 years and more than 20 years had no significant association with depression, anxiety and stress statistically. The study did not explore the contributing factors in depression, anxiety and stress but added on to the previous work regarding mental health of health science students during the COVID pandemic. Due to the cross sectional design, the study was unable to look at the long-term effect of COVID on the mental health of the participants. Also being a cross-sectional study the causal relationship between the COVID situation and higher prevalence of anxiety and depression could not be established. However, the finding of the study suggests that it is high time to start programs focusing on the student's mental health.

\section{CONCLUSION}

Mental health of health science students is adversely affected during the COVID pandemic. Hence, we recommend student focused support programs and counseling session for students particularly in health science institutes.

\section{CONFLICT OF INTEREST}

None

\section{ACKNOWLEDGEMENTS}

Researchers would like to express heartfelt thanks to all the participants of the study for their time and effort.

\section{REFERENCES}

1. Sandhu P, de Wolf M. The impact of COVID-19 on the undergraduate medical curriculum. Medical Education Online. 2020 Jan 1;25(1):1764740.

2. Azad N, Shahid A, Abbas N, Shaheen A, Munir N. Anxiety and depression in medical students of a private medical college. Journal of Ayub Medical College Abbottabad. 2017 Jan 25;29(1):123-7.

3. Risal A, Shikhrakar S, Mishra S, Kunwar D, Karki E, Shrestha B, Khadka S, Holen A. Anxiety and Depression during COVID19 Pandemic among Medical Students in Nepal.

4. Bhandari A, Bhatta N. Psychological Effects of COVID-19 and Its Measures in Nepalese Medical Students. JNMA: Journal of the Nepal Medical Association. 2020 Oct;58(230):820.

5. Worldometer. COVID-19 Coronavirus Pandemic. Available from https://www.worldometers.info [Accessed 31 ${ }^{\text {st }}$ July 2021]

6. Mahato P, Tamang P, Simkhada P, Shahi P, van Teijlingen E, Aryal N, Regmi P. Effects of COVID-19 during lockdown in Nepal. Europasian Journal of Medical Sciences. 2020 Jun $13 ; 2: 105-10$.

7. The Kathmandu Post. Nepal's Lockdown 2.0, New Covid Curbs on Travel. Available from: https://kathmandupost.com /money/2021/04/28/explained-nepal-s-lockdown-2-0-newcovid-curbs-on-travel [Accessed on $31^{\text {st }}$ July 2021]. 
8. Rayamajhee B, Pokhrel A, Syangtan G, Khadka S, Lama B, Rawal LB, Mehata S, Mishra SK, Pokhrel R, Yadav UN. How Well the Government of Nepal Is Responding to COVID-19? An Experience From a Resource-Limited Country to Confront Unprecedented Pandemic. Frontiers in public health. $2021 \mathrm{Feb}$ $17 ; 9: 85$.

9. Usher K, Durkin J, Bhullar N. The COVID(19 pandemic and mental health impacts. International Journal of Mental Health Nursing. 2020 Jun;29(3):315.

10. Xiong J, Lipsitz O, Nasri F, Lui LM, Gill H, Phan L, Chen-Li D, Iacobucci M, Ho R, Majeed A, McIntyre RS. Impact of COVID19 pandemic on mental health in the general population: A systematic review. Journal of affective disorders. 2020 Aug 8.

11. De Kock JH, Latham HA, Leslie SJ, Grindle M, Munoz SA, Ellis L, Polson R, O'Malley CM. A rapid review of the impact of COVID-19 on the mental health of healthcare workers: implications for supporting psychological well-being. BMC Public Health. 2021 Dec;21(1):1-8.

12. Saraswathi I, Saikarthik J, Kumar KS, Srinivasan KM, Ardhanaari M, Gunapriya R. Impact of COVID-19 outbreak on the mental health status of undergraduate medical students in a COVID-19 treating medical college: a prospective longitudinal study. PeerJ. 2020 Oct 16;8:e10164.

13. Halperin SJ, Henderson MN, Prenner S, Grauer JN. Prevalence of anxiety and depression among medical students during the Covid-19 pandemic: a cross-sectional study. Journal of medical education and curricular development. 2021 Feb;8: 2382120521991150 .

14. Guo AA, Crum MA, Fowler LA. Assessing the psychological impacts of CoViD-19 in undergraduate medical students. International journal of environmental research and public health. 2021 Jan;18(6):2952.

15. Tonsing KN. Psychometric properties and validation of Nepali version of the Depression Anxiety Stress Scales (DASS-21). Asian Journal of Psychiatry. 2014 Apr 1;8:63-6.

16. Le MT, Tran TD, Holton S, Nguyen HT, Wolfe R, Fisher J. Reliability, convergent validity and factor structure of the DASS-21 in a sample of Vietnamese adolescents. PloS one. 2017 Jul 19;12(7):e0180557.

17. Lovibond SH, Lovibond PF. Manual for the depression anxiety stress scales. Psychology Foundation of Australia; 1996.

18. SANOFI. Your life, reimagined: Tips for thriving in the midst of anxiety and depression. Available from: https://www.sanofi. co.za. [Accessed on 31 ${ }^{\text {st }}$ July 2021]

19. Pokhrel NB, Khadayat R, Tulachan P. Depression, anxiety, and burnout among medical students and residents of a medical school in Nepal: a cross-sectional study. BMC psychiatry. 2020 Dec;20(1):1-8.

20. Kunwar D, Risal A, Koirala S. Study of depression, anxiety and stress among the medical students in two medical colleges of Nepal. Kathmandu Univ Med J. 2016 Jan 1;53(1):22-6.
21. Albert PR. Why is depression more prevalent in women?. Journal of psychiatry \& neuroscience: JPN. 2015 Jul;40(4):219.

22. Karmacharya I, Shrestha S, Paudel S, Adhikari L, Bhujel K, Shakya KL. Mental Health Status of Nepalese Students during Novel Coronavirus Disease (nCOVID-19) Pandemic. Europasian Journal of Medical Sciences. 2020 Oct 28;2:13-21.

23. Mousa OY, Dhamoon MS, Lander S, Dhamoon AS. The MD blues: under-recognized depression and anxiety in medical trainees. PloS one. 2016 Jun 10;11(6):e0156554.

24. Basheti IA, Mhaidat QN, Mhaidat HN. Prevalence of anxiety and depression during COVID-19 pandemic among healthcare students in Jordan and its effect on their learning process: A national survey. PloS one. 2021 Apr 5;16(4):e0249716. 